IBIMA Publishing

Journal of Financial Studies \& Research

http://www.ibimapublishing.com/journals/JFSR/jfsr.html

Vol. 2016 (2016), Article ID 515420, 11 Pages

DOI: $10.5171 / 2016.515420$

Research Article

\title{
Target Prediction in M\&A Activities in the Croatian Banking Sector
}

\author{
Tomislava Pavic Kramaric ${ }^{1}$, Toni Milun ${ }^{2}$ and Ivan Pavic ${ }^{3}$ \\ University of Split, Department for Professional Studies, Split, Croatia \\ University of Split, Department for Professional Studies - Centre Zagreb, Zagreb, Croatia \\ University of Split, Faculty of Economics, Split, Croatia
}

Correspondence should be addressed to: Tomislava Pavic Kramaric

Received date: 2 March 2015; Accepted date: 9 June 2015; published date: 25 April 2016

Copyright (C) 2016. Tomislava Pavic Kramaric, Toni Milun and Ivan Pavic. Distributed under Creative Commons CC-BY 4.0

\begin{abstract}
The main focus of this paper is to analyse the characteristics that trigger the likelihood of a bank being acquired on a sample of Croatian banks in the 2002-2014 period. Using logistic regression analysis, the authors tried to explore the characteristics of target banks that also disclose the motives for acquiring a particular bank. Therefore, various variables, typically found to be the most likely factors influencing bank takeovers, were introduced in the model. Specifically, variables ROA, ROE, capital adequacy ratio, growth rate, size, market share, ownership, leverage, capital to deposits ratio and net interest margin, were aimed to capture all important aspects of bank performance. The authors have employed Student's t test that showed the significance of the size and net interest margin variable in predicting acquired banks, whereas the findings of the logit analysis show that higher values of net interest margin increase a bank's attractiveness as an acquisition target. These analyses were performed on both ranked and unranked data set. However, the authors did not find the evidence that rank transformation increases predictive power of the model.
\end{abstract}

Keywords: Croatian banking market, takeover targets, logistic regression

\section{Introduction}

The question of what drives mergers and acquisitions has intrigued many scientists over the years. It is known that mergers and acquisitions do not happen by chance, but usually occur in series or waves that have similar characteristics such as growth in stock prices, falling interest rates, i.e. they occur during the economic boom, whereas they end with the stock exchange crashes (Bruner, 2004; DePamphillis, 2010). Moreover, academic research has elaborated a number of motives or theories that drive mergers of the companies. Tichy (2001) summarizes them into five groups where one group of explanations is based on the efficiencyincreasing power of acquisitions, i.e. on synergies and corporate control hypotheses. A second group refers to the managers' interest in M\&As, i.e. to hubris, free cash flow and empire-building hypotheses. The diversification hypothesis, the third one, refers to the restructuring of the portfolio to achieve

Cite this Article as: Tomislava Pavic Kramaric, Toni Milun and Ivan Pavic (2016), " Target Prediction in M\&A Activities in the Croatian Banking Sector", Journal of Financial Studies \& Research, Vol. 2016 (2016), Article ID 515420, DOI: 10.5171/2016.515420 
the aspired risk structure. The market power hypothesis perceives the struggle for market shares and price-setting power as the dominant motive for M\&As. The last group of theories looks upon M\&As as a reaction to changes in the environment and includes disturbance and defensive hypotheses.

There is a significant body of papers that examine the likelihood of becoming a potential target in M\&A activities. Most of those papers have focused on either the Anglo-American context (e.g. Dietrich and Sorensen, 1984; Barnes, 1990, Harris et al., 2001, Wheelock and Wilson, 2000; Espahbodi and Espahbodi, 2003; Powell and Yawson, 2007), or on other developed countries (e.g. Alcalde and Espitia, 2003; Tsagkanos et al. 2006; Pasiouras and Tanna 2009). Since such studies are almost nonexistent regarding Central and Eastern European banking markets, the main goal of this paper is to show which motives drive M\&A activities in the Croatian banking market which is operating in a different legal, institutional and regulatory environment and, in a that way, to complement the aforementioned studies. Moreover, according to Amel et al. (2004), differences in regulations, institutions and market structure across countries mean that conclusions drawn from the analysis of one country should be generalized to others very carefully.

There have been many M\&As in the Croatian banking market in recent years which enables the effective analysis. Considering the future prospects of M\&A in Croatia, this issue becomes even more important. Specifically, Croatian banks are facing not only fierce local competitors, but rivalry from the single EU market is intense as well. In the context of implementing changes in regulation, banks will seek different ways to perform better with M\&As playing important roles.

However, M\&A activities might raise competition concerns since the squeeze out of some of the banks operating in the market results in an increased concentration. Nonetheless, as stipulated by Council Regulation (EC) No 139/2004 of 20 January 2004 on the control of concentrations between undertakings, the European Commission has the duty to assess mergers and acquisitions involving companies with a turnover above certain thresholds and to prevent concentrations that would significantly impede effective competition in the EEA or any substantial part of it.

Therefore, taking into account the above set theories as well as considering the availability of data, the authors will try to find out what triggers mergers and acquisitions in the Croatian banking industry or to determine which factors make certain banks attractive takeover targets.

The remaining sections of our study are organised as follows. The next section reviews related literature. The third section introduces variables chosen and describes how the sample is constructed. Empirical framework, principal findings and their implications are discussed in the fourth section. Finally, the fifth section concludes with a summary of our results.

\section{Review of Relevant Literature}

In the last few decades, a great number of studies seeking to predict potential takeover targets were conducted. These studies differ in the statistical methods used so that some studies have sought to identify takeover targets using discriminant analysis (e.g. Barnes, 1990), while the others have used probit or logit regression models (e.g. Dietrich and Sorensen, 1984; Cudd and Duggal, 2000; Harris et al., 2001; Tsagkanos et al., 2006; Powell and Yawson, 2007), while some combined both methods (e.g. Zanakis and Zapounidis, 1997; Espahbodi and Espahbodi, 2003; Pasiouras and Tanna, 2010). Some other methodological approaches have also been used in predicting takeover targets such as neural networks (e.g. Fairclough and Hunter, 1998), but overall, discriminant and logit and probit analyses have dominated this field.

These studies do not only differ by used statistical models, but also by geographical area and industries covered by research. Furthermore, there is also considerable literature in which the banking industry has largely been the subject of the analysis. Most of them cover countries like USA (e.g. 
Hannan and Rhoades, 1987; Wheelock and Wilson, 2000; Lertwachara and Boonchoo, 2006) and developed European countries (e.g. Hernando, Nieto and Wall, 2009; Pasiouras and Tanna, 2010). The only study located that specifically focused on examining the factors that trigger M\&As in Central and Eastern European countries was by Lanine and Vander Vennet (2007).

Consequently, a few studies exploring characteristics of target banks are given in the following sections in chronological order.

Wheelock and Wilson (2000) seek to identify the characteristics that make individual U.S. banks more likely to be acquired. They use end-of-quarter data for banks with at least $\$ 50$ million of assets operating in 1984 through 1993. The authors use bank-specific information and include additional measures of managerial performance that might affect the likelihood of being acquired. They find that proximity to insolvency strongly affects the likelihood that a bank will be acquired. The less well capitalized a bank is, the greater the probability that it will be acquired. They also find that banks with low earnings, low liquidity, or relatively high nonperforming loan ratios are less attractive takeover targets. Finally, the authors find that small banks in general, have been more likely to be acquired and that acquirers on average prefer not to purchase inefficient banks.

Lertwachara and Boonchoo (2006) attempted to predict merger targets among banks applying multiple discriminant analysis and logistic regression to both ranked and unranked financial ratios. The authors have identified a sample of acquired and non-acquired banks for the 1996-1999 period including firms from the New York Stock Exchange, the American Stock Exchange and NASDAQ. They compared the classification results of multiple discriminant analysis and logistic regression on both ranked and unranked data sets. The results of the analysis have indicated that rank transformation improves the predictive power of multiple regression analysis and logistic regression as well. Moreover, the authors conclude that size and insider ownership negatively influence the possibility of getting a merger bid whereas pay-out ratio and mismatch dummy positively affect the chance of being acquired.

Pasiouras and Tanna (2010) have sought to develop and evaluate prediction models for the identification of banks acquisition targets using discriminant and logit analyses. Using accounting data for 734 commercial banks in the EU, from which 168 banks were acquired over the period 1998-2002, they examined several methodological issues in model development and prediction. The analysts have used discriminant and logit analyses to estimate a variety of models, and utilized a range of criteria to evaluate the predictive accuracy of the models in terms of distinguishing the acquired banks from non-acquired ones. Although the results show that the models achieve classification accuracies higher than chance, there is nevertheless a fair amount of misclassification, which suggest difficulties in predicting bank acquisition targets.

Caiazza, Clare and Pozzolo (2012) tried to find an answer of what drives bankers to create large, often multinational banking groups studying over 24,000 banks from more than 100 countries between 1992 and 2006. The results of the analysis suggest that the probability that a bank is the target of a cross-border M\&A is on average much lower than the probability of being the target of a domestic operation, which confirms that borders have a relevant impact on corporate activities. The authors also investigate whether the targets in cross-border bank M\&As are materially different from those banks targeted in domestic M\&A deals. The main message of this paper is that, with few exceptions, domestic and foreign investors target similar banks. In particular, bank size has a positive and highly significant effect on the probability of being a target in both domestic and cross-border field. They find that the main differences between national and international M\&As are the characteristics of the countries where the banks operate. Their results also confirm that target banks in M\&A deals are typically institutions with lower than average efficiency, although this seems to be more 
the case for domestic than for cross-border deals.

\section{Data Sample and Selection of Variables}

All the data on M\&A in Croatian banking market were obtained from different issues of Banks Bulletin, a regular publication of Croatian National Bank. In order to avoid errors in identifying changes in control, we have implemented an approach suggested by Hannan and Pilloff (2009) who point out that an acquisition occurs when there is a change in control, i. e. when a bank that owns less than $50 \%$ of another banking organization's equity increases its ownership to more than $50 \%$. As a result, a number of M\&As that occurred in the Croatian banking market was identified, but after employing the above mentioned standard, the M\&A activities between members of the same ownership group, i. e. those representing internal restructuring, were excluded. Consequently, the sample was reduced to a total of 15 M\&As. The sample consisting of target companies included 15 banks, while the sample of non-target companies consisted of 112 banks.

More specifically, the sample consists of credit institutions such as banks and one savings bank (referred to as: banks), while other credit institutions such as housing savings banks were not taken into consideration.

Therefore, the analysis is conducted on a total of 127 observations; i. e. little bit less of 13 per variable which confirms the robustness of the analysis.

The sample covered M\&A activities in the 2002-2014 period. To reduce the potential effect of endogeneity on estimation results, explanatory variables are measured in the period one year prior to the year in which acquisition took place. As pointed out by Hannan and Rhoades (1987) explanatory variables are generally lagged one year, since this seemed the most reasonable length of time to allow between the observation of explanatory variables and the observation of a bank's acquisition experience. Earlier period was not covered by the analysis since the key financial data on banks involved in M\&As in the earlier period were not available. Data for most of the explanatory variables used in the analysis were obtained directly from Croatian National Bank's regular publications whereas some were calculated using balance sheet and income statements of a bank.

The variables we have chosen are representatives of those used in banking literature and in the literature on acquisition targets taking into account data availability. In order to estimate the impact of various factors that may be important in predicting takeover targets, we formed a set of common bank performance indicators for which data were available. These variables include return on assets (ROA), return on equity (ROE), capital adequacy ratio, leverage, equity to deposits ratio and net interest margin.

Since we assumed that the efficiency of the prediction model might have been enhanced by non-financial characteristics, beyond the main bank-specific financial categories mentioned above, we have also included in our model variables such as growth rate, size, ownership and market share.

Descriptions as well as the effects of various attributes of bank's performance on the likelihood of becoming a takeover target are given in the following rows.

Variables ROA and ROE were calculated dividing return after tax with total assets and equity respectively, measuring the overall profitability of a bank. Many of the previous studies have come to the conclusion that weaker banks, less efficient ones are more likely to be targets in M\&A operations precisely because they are cheaper and can be more easily restructured into efficient, profitable institutions. These less efficient targets tend to have lower levels of profitability (e.g. Akhigbe and McNulty, 2003). Therefore, we expect these variables to be negative since many of the M\&A activities were motivated by the efficiency hypothesis, i.e. by the "acquire to restructure" motive.

Net interest margin, expressed as net interest income to total assets ratio, was calculated on the basis of the data obtained from balance sheets and income 
statements published by the Croatian National Bank. Although, according to Cornett and Tehranian (1992) it belongs to the group of interest-rate risk indicators measuring the bank's exposure to interest rate risk, similar explanation regarding profitability indicators, i.e. ROA and ROE can be applied here.

Leverage ratio was computed as the ratio of equity to total assets. Since this indicator is being formed on the basis of the balance sheet data it, therefore, reflects static indebtedness showing how much of assets is financed by equity. It shows capital strength of the bank measuring the amount of protection offered to the bank by its equity. We expect this variable to have a negative sign since, following Wheelock and Wilson (2000), low capitalization puts a bank in danger of default and that sets up an incentive for acquisition. Hannan and Pilloff (2009) explain negative relationship between capital-asset ratios and the likelihood of acquisition in a way that acquirers prefer a high level of leverage because it enables them to maximize the magnitude of post-merger performance gains relative to the cost of achieving those gains.

Similar explanation can be applied to equity to deposits ratio.

Growth rate variable measures the bank's change in assets. According to Hannan and Rhoades (1987), bank growth may be indicative of higher than average expansion opportunities in the target market subsequent to acquisition and is frequently mentioned as important by practitioners in the bank acquisition process. The finding of positive coefficient would be consistent with the hypothesis that prospects for rapid growth represent a positive inducement to acquisition.

The size variable is calculated as a natural logarithm of total assets. According to Cudd and Duggal (2000), large firms are harder targets since they are more expensive, i .e. due to the greater costs of absorbing larger targets into the acquiring firms' organizational structures. Moreover, larger firms may be in a better position to employ defensive takeover strategies. There are studies that have shown the opposite (e.g. Lanine and Vander Vennet, 2007; Caiazza, 2012) which can be explained by the market power hypothesis that predicts a positive relationship between the market share variables and the probability of being targeted.

Therefore, the expected coefficient of this variable is ambiguous.

Data on capital adequacy ratio were obtained directly from Banks Bulletin. It is a common bank performance indicator that measures the bank's ability to meet regulated capital standards and still attracts loans and deposits (Cornett and Tehranian, 1992). Since, according to Wheelock and Wilson (2000), less efficient targets tend to have poor capital ratios, we expect negative coefficient with regard to the "acquire to restructure" hypothesis or inefficient management hypothesis predicting that financially vulnerable firms are more likely to be acquired and that the performance of targets will improve after the takeover.

The variable market share, calculated on the basis of assets, was introduced in the model according to market power hypothesis stating an increase of market shares and price-setting power the dominant motive for M\&As. Hannan and Pilloff (2009) in their study find both positive and negative relationship between this variable and the likelihood of being acquired, depending on the type of the acquirer. They explain the positive relationship in a way that large banks with a "brand name" are better able to exploit the advantages that a large market share may bring to a banking organization than are less known banks.

Variable ownership used in the analysis was obtained directly from Banks Bulletin. We expect that domestically owned companies are more likely becoming takeover targets since foreign companies usually have superior access to technical and financial resources but also due to the fact that domestically owned companies have better knowledge of local markets and economic environment (Berger, 2004). 
Table 1: Description of variables and their expected sign in the acquisition prediction model

\begin{tabular}{|c|c|c|}
\hline Variable & Description & $\begin{array}{l}\text { Expected } \\
\text { sign }\end{array}$ \\
\hline Return on assets (ROA) & Bank's net income after tax as a percent of its total assets & - \\
\hline Return on equity (ROE) & $\begin{array}{l}\text { Bank's net income after tax as a percent of book value of } \\
\text { its equity }\end{array}$ & - \\
\hline Capital ad equacy ratio (CAR) & $\begin{array}{l}\text { The calculation is stipulated by Credit Institutions Act } \\
\text { (Official Gazette No 159/13); articles } 112 \text { through } 115\end{array}$ & - \\
\hline Growth rate (GR) & $\begin{array}{l}\text { This variable is calculated in a following } \\
\text { way: }\left(\text { Assets }_{t}-\text { Assets }_{t-1}\right) / \text { Assets }_{t-1}\end{array}$ & + \\
\hline Size (SIZE) & $\begin{array}{l}\text { This variable is calculated as a natural logarithm of } \\
\text { bank's total assets }\end{array}$ & $+/-$ \\
\hline Market share (MS) & $\begin{array}{l}\text { Bank's assets as percent of total assets of the industry } \\
\text { observed }\end{array}$ & $+/-$ \\
\hline Ownership (OWN) & $\begin{array}{l}\text { This variable is included in the model as a dummy } \\
\text { variable ( } 1 \text { indicating foreign owned company and } 0\end{array}$ & \\
\hline Leverage (LEV) & The book value of equity to total assets ratio & - \\
\hline Equity to deposits ratio (EDR) & The book value of equity to deposits received ratio & - \\
\hline Net interest margin (NIM) & Net interest income as a percent of total assets & - \\
\hline
\end{tabular}

\section{Empirical Framework}

In this study, logistic regression model and Student's t-test were applied on data set. Logistic regression is statistical classification model used to predict the outcome of categorical dependent variable. In our case, dependent variable is binary the bank is merged or not. Value 1 is assigned to banks that were acquired, and value 0 to those that were not.

Logistic function is defined with $p(t)=\frac{1}{1+e^{-t}}$ where $t$ is a function of independent variables, whereas the results $p(t)$ are always between 0 and 1 .

Student's t-test was applied to examine the existence of statistically significant differences of means for all variables between acquired banks and non-acquired ones.
Both analyses were performed on both ranked and unranked data set. The previous studies from Lertwachara and Boonchoo (2006) and Kane, Richardson and Meade (1998) proposed rank transformation as an alternative approach to improve the predictions in economic research. Benefits of rank transformations are that they do not require normal distribution or equal variance, and they are insensitive to outliers. All variables are ranked in ascending order. A value of 1 is assigned to the lowest value, whereas a value of 127 is assigned to the highest value, except for the dummy variable ownership, with the value 1 indicating foreign ownership, and 0 otherwise.

The results of Student's t-test are presented in Table 2. 
Table 2: Student's t-test - difference of means

\begin{tabular}{|l|c|c|c|c|c|c|}
\hline & \multicolumn{3}{|c|}{ Unranked } & \multicolumn{3}{c|}{ Ranked } \\
\hline & \multicolumn{2}{|c|}{ mean } & & \multicolumn{2}{c|}{ mean } & \\
\hline & Non-target & Target & p-value & Non-target & Target & p-value \\
\hline ROA & 0,2731 & $-7,6909$ & 0,148 & 65,2143 & 54,9333 & 0,450 \\
\hline ROE & 1,8382 & $-70,7373$ & 0,132 & 65,5268 & 52,6000 & 0,338 \\
\hline CAR & 29,7509 & 39,0249 & 0,723 & 63,2500 & 69,4000 & 0,546 \\
\hline GR & 18,1050 & 1,8612 & 0,176 & 65,0893 & 55,8667 & 0,364 \\
\hline SIZE & 14,4187 & 13,4482 & $0,049^{*}$ & 66,0268 & 48,8667 & $0,090^{* *}$ \\
\hline MS & 2,7841 & 1,3849 & 0,318 & 66,1250 & 48,1333 & 0,175 \\
\hline LEV & 24,1456 & 26,5849 & 0,770 & 64,5625 & 59,8000 & 0,640 \\
\hline EDR & 1,0392 & 4,0836 & 0,152 & 64,1161 & 63,1333 & 0,942 \\
\hline NIM & 3,2429 & 4,4674 & $0,061 * *$ & 61,8036 & 80,4000 & $0,066^{* *}$ \\
\hline *statistically significant at 0,05 & & & & \\
\hline$* *$ statistically significant at 0,1 & & & & \\
\hline
\end{tabular}

The results of Student's t-test for the unranked data set show that the acquired banks had higher capital adequacy ratio, leverage, equity to deposits ratio and net interest margin, whereas variables ROA, ROE, growth rate, size and market share reported lower values than non-targets. The only significant difference was in variable size with $p=0,049$ and net interest margin with $p=0,061$. The same statistically significant results were found among ranked values.

As shown in Table 2, lower values of size variable increase a bank's attractiveness as an acquisition target. This is consistent with the explanation suggested by Palepu (1986), Cudd and Duggal (2000), Harris et al. (2001), Pasiouras and Tanna (2010) that the likelihood of acquisition decreases with the size of the firm.

Table 3: Logistic regression model

\begin{tabular}{|l|c|c|c|c|}
\hline & \multicolumn{2}{|c|}{ Unranked } & \multicolumn{2}{c|}{ Ranked } \\
\hline & Coefficients & p-value & Coefficients & p-value \\
\hline ROA & $-0,026$ & 0,825 & 0,012 & 0,624 \\
\hline ROE & $-0,012$ & 0,173 & $-0,024$ & 0,346 \\
\hline CAR & 0,001 & 0,793 & 0,014 & 0,336 \\
\hline GR & $-0,016$ & 0,543 & $-0,007$ & 0,432 \\
\hline SIZE & 0,134 & 0,660 & $-0,007$ & 0,694 \\
\hline MS & $-0,022$ & 0,829 & $-0,003$ & 0,863 \\
\hline OWN & 0,014 & 0,986 & 0,105 & 0,889 \\
\hline LEV & $-0,002$ & 0,860 & $-0,006$ & 0,496 \\
\hline EDR & $-0,033$ & 0,561 & $-0,027$ & 0,108 \\
\hline NIM & $0,622^{*}$ & 0,019 & $0,024^{*}$ & 0,028 \\
\hline
\end{tabular}

Tomislava Pavic Kramaric, Toni Milun and Ivan Pavic (2016), Journal of Financial Studies \& Research, 


\begin{tabular}{|l|c|c|c|c|}
\hline CONST & $-6,141$ & 0,220 & $-0,889$ & 0,511 \\
\hline & & & & \\
\hline Chi_Square & $20,726^{*}$ & 0,023 & 12,227 & 0,270 \\
\hline Nagelkerke R Square & 0,292 & & 0,178 & \\
\hline-2 Log Likelihood & 71,512 & & 80,011 & \\
\hline *statistically significant at 0,05 & & & \\
\hline
\end{tabular}

The results of logistic regression model for the unranked data set, as presented in Table 3, show that the likelihood of becoming a takeover bank is associated with higher values of capital adequacy ratio, size and net interest margin, and with lower values of ROA, ROE, growth rate, market share, leverage and equity to deposits ratio. Moreover, foreign owned banks are more likely to be acquired. However, the only statistically significant variable is net interest margin. The ranked data confirmed that net interest margin is the only statistically significant variable. The results of the analysis show that variable net interest margin is significant in predicting the likelihood of becoming an acquired bank though its sign is opposite to that predicted by the inefficient management hypothesis. This is also the finding in the Cudd and Duggal (2000) study suggesting that M\&As were not driven by the goal of rehabilitating underperforming firms as concluded in the study by Cummins and Rubio Misas, 2001 as well. Analysis conducted by Alcalde and Espitia (2003) show that firms that were subject to a takeover bid were not, in general, characterised by having lower profitability. Moreover, Tsagkanos, Georgopoules and Siriopoulos (2006) provide similar empirical evidence on a sample of small economy such as of Greece with logit regression model indicating that acquirers' motivation is focused on targets with good performance. The study by Lanine and Vander Vennet (2007) which was conducted using a sample of banks, reports that CEEC (Central and Eastern European countries) target banks are slightly more profitable and efficient than their peers and that Western European banks acquire CEEC banks that are not relative underperformers.

The explanation that we prefer the most is the one offered by Hernando, Nieto and Wall (2009) who state that banks with lower profitability or inefficiency might be more attractive for acquisition due to the greater opportunities for underperforming banks for improvement, but they are also more risky.

All other variables have statistically insignificant coefficients indicating that they are not important determinants of acquisition likelihood which was also the case in Hernando, Nieto and Wall (2009) study of a probability of cross-border takeovers.

Prediction results for both unranked and ranked data are presented in Tables 4 and 5.

Table 4: Prediction results for unranked data set

\begin{tabular}{|c|c|c|c|c|c|}
\hline & $\begin{array}{c}\text { Non- } \\
\text { target }\end{array}$ & Target & $\begin{array}{c}\text { Prediction } \\
\text { Accuracy }\end{array}$ & $\begin{array}{c}\text { Overall } \\
\text { Percentage }\end{array}$ & t-value \\
\hline $\begin{array}{c}\text { Non- } \\
\text { target }\end{array}$ & 112 & 0 & $100 \%$ & & \\
\hline Target & 11 & 4 & $27 \%$ & $91 \%$ & 0,828 \\
\hline
\end{tabular}

Tomislava Pavic Kramaric, Toni Milun and Ivan Pavic (2016), Journal of Financial Studies \& Research, 
Table 5 Prediction results for unranked data set

\begin{tabular}{|c|c|c|c|c|c|}
\hline & $\begin{array}{c}\text { Non- } \\
\text { target }\end{array}$ & Target & $\begin{array}{c}\text { Prediction } \\
\text { Accuracy }\end{array}$ & $\begin{array}{c}\text { Overall } \\
\text { Percentage }\end{array}$ & t-value \\
\hline $\begin{array}{c}\text { Non- } \\
\text { target }\end{array}$ & 111 & 1 & $99 \%$ & & \\
\hline Target & 15 & 0 & $0 \%$ & $87 \%$ & $-0,192$ \\
\hline
\end{tabular}

Comparing to zero-model, where all banks are predicted as non-target, with accuracy of $88 \%$, logistic regression model applied on unranked data improved accuracy to 91\%. All non-target banks were correctly predicted, which the case is with only $27 \%$ targeted banks.

The ranked data did not show improvement since not a single target bank was correctly predicted. Thus, we did not prove the conclusion of Lertwachara and Boonchoo (2006) that ranks transformation increases predictive power.

\section{Conclusions}

In recent decades, a large number of studies dealing with the prediction whether the certain company will become target in merger and acquisition transactions was generated. A significant part of these studies refers to the bank industry which is also the subject of our research.

These studies attempted to discover the factors that make a company or a bank an attractive target for takeover. In the theoretical literature, there are several theories that seek to explain the motives for undertaking M\&A transactions. Since the results of previous studies vary depending on an industry which is the subject of the analysis, on geographic area that is analysed, as well as on the time period covered by the analysis, the authors wanted to find out what motivates acquisitions of banks in Croatia in the 2002 - 2014 period.

The authors used ten variables in the analysis, specifically ROA, ROE, capital adequacy ratio, growth rate, size, market share, ownership, leverage, capital to deposits ratio and net interest margin, which were aimed to cover all important aspects of bank operations, and were selected based on availability and after consulting papers dealing with this same issue.

Student's $t$ - test showed the significance of the size and net interest margin variable in predicting acquired banks.

The results of the logit analysis show that banks with higher net interest margin are more likely to be takeover targets. Although, some might find this finding surprising since it is inconsistent with the hypothesis that acquisitions serve to transfer assets from poorly managed to better managed firms, our explanation is that not all M\&As are primarily motivated by efficiency considerations as proved by many studies. However, the authors do not find evidence that bank's characteristics such as ROA, ROE, capital adequacy ratio, growth rate, size, market share, ownership, leverage, equity to deposits ratio play the role in explaining the likelihood of acquisition.

Student's t-test as well as the logit regression analysis were performed on both ranked and unranked data set. The results we obtained using the unranked data set were confirmed using ranked values as well although we did not prove that rank transformation increases the predictive power of the model.

Overall, we can say that it is difficult to predict targets since this study, like many others, does not yield a clear picture of the factors leading to takeover. As emphasized by Harris et al. (2001), the problem is confounded by the fact that a merger 
involves two firms simultaneously; thus, there may be no single true effect of a firm's characteristics on the probability of its being acquired. Moreover, the model may be enhanced by additional, primarily non-financial characteristics that might play an important role in M\&As. Therefore, we hope this to be added in future research.

\section{References}

1. Adams, R. M. (2009),'Which Credit Unions are Acquired? A Comment', Journal of Financial Services Research, 36 (2-3), 253-254

2. Akhigbe, A. and McNulty, J. E. (2003), 'The profit efficiency of small US commercial banks', Journal of Banking \& Finance, 27(2), 307-325

3. Alcalde, N. and Espitia, M. (2003), "The Characteristics of Takeover Targets: The Spanish Experience 1991-1997', Journal of Management and Governance, 7 (1), 1-26

4. Amel, D. et al. (2004), 'Consolidation and efficiency in the financial sector: A review of the international evidence', Journal of Banking \& Finance, 28 (10), 2493-2519

5. Barnes, P. (1990), 'The Prediction of Takeover Targets in the U.K. by Means of Multiple Discriminant Analysis', Journal of Business Finance\&Accounting, 17(1), 73-84

6. Bruner, R.F. (2004), Applied Mergers and Acquisitions, Hoboken, John Wiley\&Sons

7. Caiazza, S, Clare, A. and Pozzolo, A. F. (2012), 'What do bank acquirers want? Evidence from worldwide bank M\&A targets', Journal of Banking \& Finance, 36 (9), 2641-2659

8. Cornett, M. M. and Tehranian, H. (1992), 'Changes in corporate performance associated with bank acquisitions', Journal of Financial Economics, 31 (2), 211-234

9. Council Regulation (EC) No 139/2004 of 20 January 2004 on the control of concentrations between undertakings, [Online]. [February 10, 2015], Available: http://eur-lex.europa.eu/legal-

content/EN/ALL/?uri=CELEX:32004R0139

10. Croatian National Bank, Banks Bulletin, No. 1-27, Zagreb, 2001-2014, [Online]. [December 1, 2014], Available: http://www.hnb.hr/publikac/hpublikac.ht $\mathrm{m}$

11. Credit Institutions Act, Official Gazette No 159/13, [Online]. [January 10, 2015], Available:

http://www.hnb.hr/propisi/zakoni-htmpdf/e-zakon-o-kreditnim-institucijama159-2013.pdf

12. Cudd, M. and Duggal, R. (2000), 'Industry Distributional Characteristics of Financial Ratios: An Acquisition Theory Application', The Financial Review, 35 (1), 105-120

13. Cummins, J. D. and Rubio-Misas, $M$. (2001), 'Deregulation, consolidation and efficiency: evidence from the Spanish insurance industry', [Online]. Working Paper Series 02-01, Wharton Financial Institutions Center, Philadelphia, PA., [February 2, 2015], Available: http://papers.ssrn.com/sol3/papers.cfm?a bstract_id=294687

14. DePamphilis, D. M. (2010) Mergers, Acquisitions, and Other Restructuring Activities, $5^{\text {th }}$ ed., Academic Press

15. Dietrich, J. K. and Sorensen, E. (1984), 'An Application of Logit Analysis to Prediction of Merger Targets', Journal of Business Research, 12, 393-402

16. Espahbodi, H. and Espahbodi, P. (2003), 'Binary choice models and corporate takeover', Journal of Banking \& Finance, 27 (4), 549-574

17. Fairclough, D. and Hunter, J. (1998),'The Ex-ante Classification of Takeover Targets Using Neural Networks', Advances in Computational Management Science, 2, 381-388

18. Hannan, T. H and Pilloff, S. J. (2009), 'Acquisition Targets and Motives in the Banking Industry', Journal of Money, Credit and Banking, 41(6), 1167-1187 
19. Hannan, T. H. and Rhoades, S. A. (1987), 'Acquisition Targets and Motives: The Case of the Banking Industry', The Review of Economics and Statistics, 69 (1), 67-74

20. Harris R. S. et al., (2001), 'Characteristics of Acquired Firms: Fixed and Random Coefficients Probit Analyses', 164-184

21. Hernando, I., Nieto, M. J. and Wall, D. L. (2009), 'Determinants of domestic and cross-border bank acquisitions in the European Union', Journal of Banking \& Finance, 33 (6), 1022-1032

22. Kane, G. D., Richardson, F. M. and Meade, N. L. (1998), 'Rank Transformations and the Prediction of Corporate Failure', Contemporary Accounting Research, 15 (2), 145-166

23. Lanine, G. and Vander Vennet, R. (2007), 'Microeconomic determinants of acquisitions of Eastern European banks by Western European banks', Economics of Transition, 15 (2), 285-308

24. Lertwachara, K. and Boonchoo, $P$. (2006),'An Application of Rank Transformation: Merger Target Predictions', 33-42

25. Palepu, K. G. (1986),'Predicting takeover targets', Journal of Accounting and Economics, No 8, 3-35

26. Pasiouras, F. and Tanna, S. (2010),'The prediction of bank acquisition targets with discriminant and logit analyses:

methodological issues and empirical evidence', [Online]. Research in International Business and Finance, 24 (1), 39-61 (Revised Version), [February 10, 2015], Available: http://papers.ssrn.com/sol3/papers.cfm?a bstract_id=1330337

27. Powell, R. and Yawson, A. (2007),'Are Corporate Restructuring Events Driven by Common Factors? Implications for Takeover Predictions', Journal of Business Finance\&Accounting , 34 (7\&8), 1169-1192

28. Stevens, D. L. (1973), 'Financial Characteristcs of Merged Firms: A Multivariate Analysis', Journal of Financial and Quantitative Anaysis, p. 149-158

29. Ticy, G. (2001), 'What Do We Know about Success and Failure of Mergers?, Journal of Industry, Competition and Trade, 1 (4), 347-394

30. Tsagkanos, A. et al. (2006), 'Predicting Takeover Targets: New Evidence from a Small Open Economy', International Research Journal of Finance and Economics, Issue 4, 183-194

31. Wheelock, D. C. and Wilson, P. W. (2000), 'Why Do banks Disappear? The Determinants of U.S. Bank Failures and Acquisitions', The Review of Economics and Statistics, 82 (1), 127-138

32. Zanakis, Sh. and Zapounidis, C. (1997), 'Prediction of Greek company takeovers via multivariate analysis of financial ratios', Journal of the Operational Research Society, $48,678-687$ 